FACTA UNIVERSITATIS

Series: Law and Politics Vol. 15, N N $^{\circ}$ 2017, pp. 385 - 395

https://doi.org/10.22190/FULP1704385S

Review Paper

\title{
SUSPENDED SENTENCE IN CRIMINAL LEGISLATION OF THE REPUBLIC OF SERBIA
}

UDC 343.281(497.11)

\section{Dragana Spasić}

University of Kragujevac, Faculty of Law, Kragujevac, Republic of Serbia

\begin{abstract}
Suspended sentence, as a cautionary measure, is one of the most frequently applied criminal sanctions. As such, it exists in almost all modern legislations. In this paper, after providing a brief overview of the historical development of the suspended sentence, the author analyzes the concept of a suspended sentence in the criminal law of the Republic of Serbia, by focusing on the concept and characteristics of suspended sentence, conditions for imposing a suspended sentence, revocation of a suspended sentence, as well as a suspended sentence with protective supervision. The second part is dedicated to the application of suspended sentence in domestic judicial practice. On the basis of statistical data, the author presents a comparative overview of the frequency of pronouncing suspended sentence in three time periods (the 1970s, the 1990s, and after the democratic changes in 2000), which were marked by different political, economic and other societal characteristics.
\end{abstract}

Key words: cautionary measures, suspended sentence, suspended sentence with protective supervision, probationary period.

\section{INTRODUCTORY REMARKS}

Suspended sentence exists today in almost all contemporary criminal legislations, either as a criminal sanction sui generis or as a suspension of a prison sentence. With a judicial admonition, they constitute a special type of criminal sanctions in our criminal legislation, based on the assumption that the objectives of punishment in certain cases can also be achieved under conditions less restrictive than imprisonment (Malešević, Počuča, 2016: 391). There are different views in the criminal theory regarding the time and place of the occurrence of suspended sentence as a criminal law measure and the idea which it is based on. Some authors believe that the roots of suspended sentence can be traced back to the $13^{\text {th }}$ century, in France, while others consider that suspended sentence is a legislative innovation that has first occurred in the $19^{\text {th }}$ century (Bejatović, 1986: 23-25).

Received July $25^{\text {th }}, 2017$ / Accepted November $27^{\text {th }}, 2017$

Corresponding author: Dragana Spasić, LL.M., Teaching Associate

Faculty of Law, University of Kragujevac, 34000 Kragujevac, Republic of Serbia

E-mail: dspasic@jura.kg.ac.rs 
Despite the fact that statutory regulation of suspended sentence is linked only to the $19^{\text {th }}$ century, it should be borne in mind that the thought on which suspended sentence rests existed in the medieval law (Bejatović, 1986: 23-25). According to Pradell, in the beginning of the 13th century, there was a need in court practice to avoid the execution of conviction for certain crimes, and thus conviction began to be replaced by a contract between the judge and the perpetrator, which allowed the perpetrator to avoid the sanction (recognizance or binding over on good behavior). The perpetrator was being left unattended, but he was obliged to comply with the court orders (Pradel, 2009: 37-38). In case of failure to fulfill these orders, the court would apply the appropriate sanction to the perpetrator. Consequently, in literature, suspended sentence is often described as "Sword of Damocles" hanging over a head of a conditionally convicted person during a probationary period (Weatherburn, Bartels, 2008: 667). This practice of the courts, along with the "the benefit of clergy" and the postponement of the execution of sanctions (judicial reprieve), represent the initial phase in the development of what we now call probation. ${ }^{1}$ However, bearing in mind that the cases of application of the suspended sentence did not have their basis in the laws or other written rules, and that there were no precise criteria for their application, the beginning of the suspended sentence should be related to the practice of the English courts in the first half of the 19th century (Bejatović, 1986: 25).

As far as Serbia is concerned, the first traces of suspended sentence can be found in the $15^{\text {th }}$ century. Nevertheless, suspended sentence was established in the criminal legislation of the Republic of Serbia by the Criminal Code of Kingdom of Yugoslavia in 1929 (after several unsuccessful attempts, starting from legal act on suspended sentence in 1906). From the very introduction into our legislation, and during the period after World War II, as well as the period of forming separate republics (following the disintegration of the SFRY) until now, the suspended sentence has changed its nature - from a mode of imprisonment to independent criminal sanction. The applicable Criminal $\operatorname{Code}^{2}$ (hereinafter: CC) gives suspended sentence the status of an independent criminal sanction, which is characteristic of the Anglo-Saxon system of suspended sentence. However, having in mind that the perpetrator is not threatened with the completion of a criminal proceeding in which the penalty would be subsequently assessed and imposed, but with the penalty that has already been determined, the suspended sentence in our law is closer to the continental type of suspended sentence (Đokić, 2007: 190).

Consequently, it can be argued that a suspended sentence in our law belongs to the socalled "mixed system" of suspended sentence. It is pronounced when a perpetrator is to be sentenced to imprisonment of up to two years, in cases where it may be expected that the purpose of punishment could also be achieved with the admonition with the threat of punishment. Even though the term of imprisonment determined has remained the same as in the previous legislation, the CC no longer envisages the possibility of suspending a fine. This stance of the legislator is acceptable, since the threat of fine significantly changes the quality of suspended sentence. The threat of imprisonment is much more effective given the increased degree of intimidation (Đokić, 2007: 190).

\footnotetext{
1 "The benefit of clergy" was a practice in which members of the clergy could seek exemption or mitigation of the sentence before the civil (rather than ecclesiastical) courts, while judicial adjournment meant postponing imposition of the sentence in order to allow the perpetrator to seek forgiveness from the monarch (Sevdiren, 2011: 26).

${ }^{2}$ The Criminal Code of Republic of Serbia, Official Gazette of RS, 85/2005, 88/2005, 107/2005, 72/2009, $111 / 2009,121 / 2012,104 / 2013,108 / 2014$ and 94/2016
} 


\section{SUSPENDED SENTENCE IN CRIMINAL CODE OF THE REPUBLIC OF SERBIA}

\subsection{Concept and characteristics of suspended sentence}

By analyzing Article 64 of the CC, which specifies the purpose of suspended sentence and judicial admonition (cautionary measures), a conclusion can be drawn on the characteristics of these measures, which are at the same time the requirements for pronouncing them. Suspended sentence and judicial admonition can be imposed only for lesser offenses, since only in such crimes can the purpose of the punishment be achieved even without imposing a sanction. The circle of lesser crimes is determined on the basis of the penalty determined in particular case and penalty provided for in $\mathrm{CC}$. The intent behind these measures is to avoid the imposition of the penalty, i.e. its negative consequences, when the purpose of criminal sanctions can also be achieved with admonition, with the threat of punishment (suspended sentence) or a caution alone (judicial admonition) (Article 64 of CC). Finally, the special-preventive character of cautionary measures requires that the offense is committed by a perpetrator toward whom suspended sentence, or judicial admonition, will have sufficient influence and deter him from committing criminal offenses in the future (Stojanović, 2016: 330).

The essential elements of suspended sentence, as an independent criminal sanction, are punishment and probationary period (Stojanović, 2016: 332). Namely, the court determines the punishment of the perpetrator by a suspended sentence and at the same time determines that it will not be enforced, provided that the convicted person does not commit a new criminal offense during the period set by the court, which may not be shorter than one or longer than five years (probationary period) (Article 65, paragraph 1 of the CC). In addition to the basic obligation not to commit a new criminal offense, the court may also order the convicted person to fulfill special obligations: to restore the material gain acquired through the commission of a criminal offense within the time limit set by the court (within the probationary period), to compensate the damages caused by the criminal offense or to fulfill other obligations provided in provisions of criminal legislation. ${ }^{3}$ Unless revoked, conditional sentence does not impair the legal consequences of conviction and is removed from the criminal records by the commencement of legal rehabilitation if the convicted person does not commit a new criminal offense within the probationary period and a year after its expiration (Article 98, paragraph 2).

\subsection{The requirements for pronouncing suspended sentence}

The legislator prescribed conditions for imposing suspended sentence in Article 66 of the $\mathrm{CC}$. These conditions can be objective, which relate to the determined or prescribed punishment, and subjective, which relate to the personality of the perpetrator of the crime.

In accordance with Article 66, paragraph 1, suspended sentence may be imposed in cases where the perpetrator is to be punished with imprisonment of less than two years. ${ }^{4}$

\footnotetext{
${ }^{3}$ When a father takes a child whose care is entrusted to the mother and refuses to return him to his mother and thereby prevents the execution of the decision on the awarding of a minor, he may be obligated to return the child to the mother within a certain period of time. Judgment of District Court in Belgrade, Case Ap. 730/05 and Judgment of Third Municipal Court in Belgrade, Case Ap. 1144/02 (Trešnjev, 2008: 36)

${ }^{4}$ By comparison, the Criminal Code of Croatia stipulates that suspended sentence may be applied to the perpetrator of a criminal offense when the court pronounce imprisonment not exceeding one year or a fine (Article 56, para. 2). Unlike our criminal legislation, the Croatian criminal law stipulates that the court may impose on a perpetrator sentenced to a fine or imprisonment sentence of more than one, but less than three years, a suspended sentence for only
} 
The court first sets a penalty according to the general sentencing rules, and then determines it and pronounces a suspended sentence. By interpreting the said article, it can be concluded that in order to pronounce a suspended sentence in a particular case, it is not important whether the perpetrator committed one or more crimes, as long as the imprisonment does not exceed two years. Therefore, conditional sentence can also be imposed on a perpetrator who has committed several criminal offenses, if the court, using general principles on sentencing for joint offense, determines the punishment of less than two years. Apart from the conditions that relate to the determined punishment, the legislator has also envisaged a condition in respect of stipulated imprisonment, whose aim is to exclude the possibility of applying suspended sentence in serious criminal offenses. Namely, for criminal offenses punishable by imprisonment of ten years or more, a suspended sentence may not be pronounced (Article 66 paragraph 2 of the CC).

The scope of application of suspended sentence is also limited by the requirement related to the perpetrator. Namely, the legislator held the view that in relation to certain persons the possibility of applying a suspended sentence should be excluded; thus, as an additional condition, it is foreseen that a suspended sentence cannot be pronounced if more than five years have not elapsed since the sentence of imprisonment pronounced to perpetrator for premeditated offense became final (Article 66, paragraph 3). ${ }^{5}$ In assessing whether it is justifiable to impose a suspended sentence in a particular case, the court is obliged to take into consideration the circumstances surrounding the perpetrator's personality, his previous conduct, the conduct of the perpetrator after the crime was committed, the degree of culpability and other circumstances under which the crime was committed. ${ }^{6}$ In accordance with its purpose, the court will pronounce a suspended sentence when it assesses that it is not necessary to apply the sentence, because it can be expected that, given the personality of the perpetrator and other circumstances, the admonition with the threat of punishment will have sufficient effect on him to deter him from further commission of criminal offenses (Stojanović, 2016: 334).

\subsection{Revocation of suspended sentence}

Our criminal law provides for three grounds for revoking probation: a) the commission of a new criminal offense; b) a previously committed criminal offense; and c) the failure to fulfill certain obligations (Stojanović, 2016: 334).

\footnotetext{
part of the sentence if it assesses that there is a high degree of probability that even without the execution of the entire sentence, he/she will not commit criminal offenses in the future; Article 57 Criminal Code of Republic of Croatia, The Official Gazette of the Republic of Croatia, 125/11, 144/12, 56/15, 61/15. Under the Criminal Code of Bosnia and Herzegovina, suspended sentence may be imposed when a perpetrator has been sentenced to imprisonment for a term not exceeding two years or to a fine; Article 59, para. 3. Criminal Code of Bosnia and Herzegovina, "Official Gazette of BiH”, 3/03, 32/03, 37/03 54/04, 61/04, 30/05, 53/06, 55/06, 32/07, 8/10, 47/14, 22/15, 40/15.

${ }^{5}$ Thus, the District Court in Belgrade found that the conditions for pronouncing suspended sentence were not met when the perpetrator was sentenced one year earlier for the same criminal offense of domestic violence to the prison sentence and the security measure of compulsory drug addiction treatment, and after serving the sentence, continued to endanger the physical and mental integrity of his parents, because they refused to give him money to buy drugs. Judgment of District Court in Belgrade, Case Ap. 2894/04 and Judgment of Third Municipal Court in Belgrade, Case Ap. 609/04 (Trešnjev, 2008: 35-36)

${ }^{6}$ In the event that the injured party jumped out of a moving vehicle in order to prevent the accused from committing sodomy, resulting in a concrete risk of serious consequences for her, the use of suspended sentence is not possible, especially when considering the gravity of the perpetrated criminal offense and the seriousness of endangering the protected good.
} 
The revocation of a suspended sentence for a new criminal offense may be mandatory and optional. The court is obliged to revoke a suspended sentence if the convicted offender committed one or more crimes during the probation and is sentenced to imprisonment of two years or more. If a convicted person committed one or more offenses for which he is sentenced to imprisonment of under two years or a fine, having considered all the circumstances relating to the committed crimes and the perpetrator, the nature of the offenses, their significance and motives of the perpetrator, the court shall decide whether to revoke a suspended sentence. ${ }^{7}$ In addition, the court is bound by the prohibition of pronouncing a suspended sentence if for the offenses established in the suspended sentence and for new criminal offenses, the court shall impose a sentence of imprisonment of more than two years.

In addition to this, the court shall revoke a suspended sentence if, after its pronouncement, the court determines that the convicted person committed a criminal offence prior to ordering of a suspended sentence and if in the consideration of the court there would have been no grounds for ordering a suspended sentence had such offence been known (Article 68 paragraph 1 of the CC).

Finally, conditional sentence can be revoked due to non-fulfillment of certain obligations. In case where the convicted person is ordered by a suspended sentence to return the material gain obtained by the criminal act, compensate the caused damages, or fulfill some other obligation stipulated by the criminal law provisions, and fails to fulfill such obligation within the period set in the judgment, the court may proceed in one of four ways: to extend the deadline for fulfillment of the obligation during the period of probation, to replace the existing obligation with another obligation provided by law or release the convicted person from the fulfillment of that obligation, if there are justifiable reasons for this, or may revoke the suspended sentence and order the penalty determined in the suspended sentence. ${ }^{8}$ Therefore, in case of failure to meet the envisaged obligations, suspended sentence will not necessarily be revoked, but the court "is obliged before making the decision to examine whether there are justifiable reasons why the convicted person did not fulfill the set obligation" (Stojanović, 2016: 335).

The rule is that conditional conviction can be revoked only during the probationary period. In exceptional cases, the court may revoke a suspended sentence not later than one year from its expiration, when the convict commits a new criminal offense that entails the revocation of the suspended sentence during the time of probation, whereas this is determined by judgment after the expiry of the probationary period, as well as when the convicted person fails to fulfill some of the ordered obligations within the period set by the judgment. ${ }^{9}$

\footnotetext{
${ }^{7}$ Thus, the second instance court ruled in one case that the conditions for the revocation of the suspended sentence were fulfilled when the offender committed the same kind of criminal offense as before, during the time of probation, whereas all the offenses were committed in the same manner - forcefully, since it is obvious that suspended sentence as an admonition with the threat of punishment did not have the sufficient effect on the accused to deter him from committing any more criminal offenses. Judgment of District Court in Belgrade, Case Ap. 143/95, and Judgment of Fourth Municipal Court in Belgrade, Case Ap. 1011/94, (Simić, 1998: 48-49).

${ }^{8}$ According to the judgment of the District Court in Belgrade, the conditions for revoking the suspended sentence are met when the defendant fulfilled the obligation and indemnified one of the injured parties, if he did not do so against the other injured party. Judgment of District Court in Belgrade, Case Ap. 151/03; Judgment of Fourth Municipal Court in Belgrade, Case Ap. 581/99, (Trešnjev, 2008: 39).

${ }^{9}$ The additional period of one year for the revocation of a suspended sentence has the significance of a limitation period in which the second instance decision must be made. When the additional period of one year has expired
} 
Due to the low rate of revocation of suspended sentence (according to some surveys, this percentage is 6-7\% in our country) (Stojanović, 2016: 332), it is usual for suspended sentences to be considered an effective criminal sanction. However, this should be accepted with a certain reserve because in our judicial practice, the institute of facultative revocation of suspended sentence is often used, where instead of revocation, the court decides on a new suspended sentence (Stojanović: 2012: 308).

\subsection{Suspended sentence with protective supervision}

Besides the so-called classical form of suspended sentence, almost all modern criminal legislatures recognize a suspended sentence with protective supervision as a special variant of suspended sentence. The basis for introducing this form of suspended sentence is the knowledge that there are different categories of delinquents toward who do not have to be subjected to the sentence of imprisonment in order to achieve the general purpose of criminal sanctions and the protective function of criminal law. Namely, these are two categories of delinquents. On the one hand, there are the perpetrators who are most likely not to commit crimes in the future. The second group consists of perpetrators who are reasonably suspected to be able to refrain from repeating the criminal act if left on one's own; therefore, it is necessary to provide assistance and control in order to achieve the purpose of suspended sentence (Đorđević, 2011: 64).

The essence of a suspended sentence with protective supervision is reflected in the obligations that the court may impose on the conditionally sentenced persons. These obligations are regulated by Article 73 of the $\mathrm{CC}$, as well as by the relevant provisions of the Act on the Execution of Non-Custodial Sanctions and Measures ${ }^{10}$ and the Rules on the Execution of Suspended Sentence with Protective Supervision (hereinafter: the Rules) ${ }^{11}$. In addition to the obligation of the convicted person to report to the body competent for enforcement of supervision within the period determined by that body, the protective supervision may contain one or more of the following obligations: training of the offender for a particular profession, accepting employment consistent with the offender's abilities, fulfillment of the obligation to support family, child care and child-rearing and other family duties, refraining from visiting particular places, establishment or events if that may present an opportunity or incentive to re-commit criminal offences, timely notification of the change of residence, address or place of work, refraining from drug and alcohol abuse, treatment in a competent medical institution, visiting particular professional and other counseling centers or institutions and adhering to their instructions, and eliminating or mitigating the damage caused by the offence, particularly reconciliation with the victim of the offence.

However, despite the fact that suspended sentence and suspended sentence with protective supervision are envisaged as measures that should contribute to reducing the number of prisoners, suspended sentence "was never applied in an adequate manner due to the lack of an appropriate mechanism in the social protection system" (Soković, 2009: 194).

In September 2014, a new Act on the Execution of Non-Custodial Sanctions and Measures (hereinafter: the ENCSM Act) came into force. This Act (in Articles 34-37)

during the duration of the appeal proceedings, there are no longer conditions for revoking a suspended sentence. Judgment of the District Court in Belgrade, Case Ap.1899/00 (Simić, 2000: 51-52).

${ }^{10}$ The Act on the Execution of Non-Custodial Sanctions and Measures, Official Gazette of RS, 55/2014

${ }^{11}$ Rules on the Execution of Suspended Sentence with Protective Supervision, Official Gazette of RS, 20/2008 
regulates the execution of a suspended sentence with protective supervision as well as the competence of the Commissioner Service within the Directorate for Execution of Criminal Sanctions of Ministry of Justice RS. The procedure for the execution of suspended sentences with protective supervision is initiated by the court of first instance. The court is obliged to submit an enforceable decision, including the data on the personality of the convicted person obtained during the criminal proceedings, to the competent commissioner office within three days from the date when it became enforceable (Article 34 of the ENCSM Act). The competent commissioner for the execution of suspended sentence with protective supervision is determined according to the place of residence or temporary residence of the convicted person. The commissioner is obliged to inform the convicted person about the purpose of the protective supervision, his obligations and the consequences of the failure to complete such obligations and, in cooperation with the convicted person, draft the program for the enforcement of the protective supervision. The program is drafted according to the obligations and deadlines imposed by the court decision, the personal characteristics of the convicted person, his social circumstances, health condition, abilities, level of education and qualification, employment and other circumstances (Article 10 of the Rules). The program of supervision shall be submitted to the competent court and to the appropriate authority, institution, organization i.e. employer (Article 35, para. 4 of the ENCSM Act). The convicted person has the right to appeal to the competent court within three days from the day of getting familiar with the program (Article 35, para.5 of the the ENCSM Act). The Commissioner is obliged to inform the Commissioner Service about the beginning and completion of the supervision; in the event that the protective supervision does not start within 30 days from the date of the receipt of the enforceable decision, or the convicted person does not accept the execution of the protective supervision, the Commissioner must notify the court that has ordered the protective supervision. If the convicted person does not fulfill the obligations assigned to him during the implementation of the program, the commissioner is obliged to inform the court and the Commissioner Service about this. If the convicted person has a justifiable reason for not fulfilling the obligations set by the program, he is obliged to notify the commissioner about those reasons as soon as possible (Article 14 of the Regulation). Depending on the success achieved in the execution of the protective supervision, the commissioner may in the report propose to the court to replace or terminate certain obligations of the convicted person, or if, on the basis of the positive results, he considers that the purpose of the protective supervision is fulfilled, he may suggest that the protective supervision be abolished before the expiry of the probationary period (Article 37 of the ENCSM Act).

\section{APPLICATION OF SUSPENDED SENTENCE IN SERBia: GENERAL INDICATORS}

For many years suspended sentence has been the most frequently pronounced sanction in the practice of our courts, although it is noticeable that suspended sentence with protective supervision, as a modality of suspended sentence, is much less applied. In order to gain a better insight into the application of suspended sentence in the territory of the Republic of Serbia, this section will present statistical data on the frequency of pronouncing suspended sentence in different time frames (in the 1970s, 1990s and after the year 2000), all of which have different and specific political, economic and other features. These periods are: the period of the 1970s, when Serbia was part of the SFRY, characterized by 
the political and economic stability of the country and the growth of standard ${ }^{12}$; the period of the 1990s, marked by the disintegration of Yugoslavia, wars, sanctions of the international community and hyperinflation; and the period after the democratic changes in 2000 and Serbia's pro-European orientation.

Table 1 The proportional representation of suspended sentence in the total number of sentenced criminal offenses in the period from 1972 to 1976

\begin{tabular}{cccc}
\hline & $\begin{array}{c}\text { Total number of } \\
\text { convicted persons }\end{array}$ & $\begin{array}{c}\text { Conditionally sentenced persons } \\
\text { Number }\end{array}$ & $\%$ \\
\hline 1972 & 44218 & 21405 & 48.4 \\
1973 & 39008 & 16992 & 43.6 \\
1974 & 43442 & 18340 & 42.2 \\
1975 & 46815 & 20622 & 44.0 \\
1976 & 48737 & 20284 & 41.6 \\
\hline
\end{tabular}

From the data presented in Table 1 it follows that the share of suspended sentences in the total number of criminal sanctions applied in the period from 1972 to 1976 amounts to $44 \%$.

Table 2 The proportional representation of suspended sentence in the total number of sentenced criminal offenses in the period from 1993 to 1997

\begin{tabular}{lccc}
\hline & Total number of & \multicolumn{2}{c}{ Conditionally sentenced persons } \\
\cline { 3 - 4 } convicted persons & Number & $\%$ \\
\hline 1993 & 32922 & 15891 & 48.3 \\
1994 & 33461 & 20991 & 62.7 \\
1995 & 36664 & 22527 & 61.4 \\
1996 & 37206 & 21027 & 56.5 \\
1997 & 39301 & 22888 & 58.2 \\
\hline
\end{tabular}

If we take the period from 1993 to 1997 for the timeframe of the research, we see that the percentage of conditionally sentenced persons in the total number of convicted persons is $57.42 \%$, which is a significant increase compared to the previous period by more than 13 index points.

From the data presented in Table 3 and Table 4, it can be concluded that in the structure of the pronounced criminal sanctions on the territory of Serbia, between 2006 and 2015, suspended sentence amounts to 55.83\%. There is a slight decline in its participation in the total number of sanctions imposed in the period from 2010 to 2014, with a further increase in 2015. A record number of imposed suspended sentences was recorded in 2010, when the percentage representation of this sanction in the total number of criminal sentences was $59.2 \%$. The number of pronounced suspended sentences in the observed period confirms the hypothesis that, throughout history, suspended sentence was the most common criminal sanction in the practice of our courts, regardless of the different economic, political and other societal conditions and stability of the country.

${ }^{12}$ For this reason, many call this period "the golden seventies“. 
Table 3 The proportional representation of suspended sentence in the total number of sentenced criminal offenses in the period from 2006 to 2015

\begin{tabular}{lccc}
\hline & Total number of & \multicolumn{2}{c}{ Conditionally sentenced persons } \\
\cline { 3 - 4 } convicted persons & Number & $\%$ \\
\hline 2006 & 41422 & 21504 & 51.9 \\
2007 & 38694 & 21702 & 56.1 \\
2008 & 42138 & 24131 & 57.3 \\
2009 & 40880 & 23382 & 57.2 \\
2010 & 21681 & 12833 & 59.2 \\
2011 & 30807 & 18110 & 58.8 \\
2012 & 31322 & 17169 & 54.8 \\
2013 & 32241 & 17152 & 53.2 \\
2014 & 35376 & 18307 & 51.7 \\
2015 & 33189 & 19920 & 58.1 \\
\hline
\end{tabular}

Table 4 Convicted adult persons according to the imposed criminal sanctions

\begin{tabular}{lrrrrrrrrrr}
\hline & \multicolumn{2}{c}{2011} & \multicolumn{2}{c}{2012} & \multicolumn{2}{c}{2013} & \multicolumn{2}{c}{2014} & \multicolumn{2}{c}{2015} \\
\cline { 2 - 11 } & number & $\%$ & number & $\%$ & number & $\%$ & number & $\%$ & number & $\%$ \\
\hline Prison & 8158 & 26.5 & 10212 & 32.6 & 11204 & 34.8 & 13026 & 36.8 & 8820 & 26.6 \\
Suspended Sentence & 18110 & 58.8 & 17169 & 54.8 & 17152 & 53.2 & 18307 & 51.7 & 19290 & 58.1 \\
Fine & 3665 & 11.9 & 3138 & 10.0 & 3141 & 9.7 & 3119 & 8.8 & 2722 & 8.2 \\
Judicial Admonition & 181 & 0.6 & 225 & 0.7 & 190 & 0.6 & 341 & 1.0 & 694 & 2.1 \\
Other & 693 & 2.25 & 578 & 1.8 & 554 & 1.7 & 583 & 1.6 & 1663 & 5.0 \\
\hline Total & 30807 & 100 & 31322 & 100 & 32241 & 100 & 35376 & 100 & 33189 & 100 \\
\hline
\end{tabular}

The analysis of the data obtained from the Republic Statistics Institute on pronounced suspended sentences for the period from 2010 to 2015 shows that suspended sentence in the specified timeframe of the research was pronounced mainly for crimes against property $(23.0 \%)$, crimes against marriage and family, and criminal offenses against the safety of public transport. It is interesting that the participation of these three groups of crimes in the total number of pronounced suspended sentences amounts to almost $50 \%$ (more precisely $47 \%$ ).

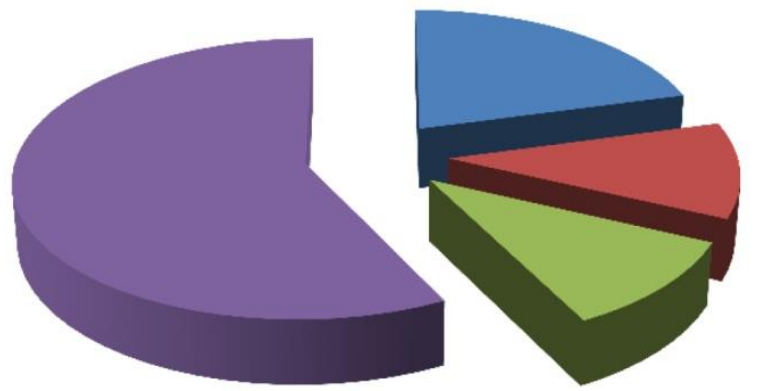

- Criminal offenses against property

- Criminal offenses against marriage and family

Criminal offenses against road traffic safety

- Other

Fig. 1 Conditionally sentenced persons according to the group of criminal offenses 
Unlike a suspended sentence that falls under the most frequently applied sanctions on the territory of our country, conditional sentencing with protective control is applied far less frequently. This is also indicated by the data presented in Table 5.

Table 5 The number of pronounced suspended sentences with protective supervision in the period 2010- 2014

\begin{tabular}{lcccccc}
\hline Year & 2010 & 2011 & 2012 & 2013 & 2014 & Total \\
\hline $\begin{array}{l}\text { The number of pronounced suspended sentences } \\
\text { with protective supervision }\end{array}$ & 3 & 21 & 11 & 14 & 29 & 78 \\
\hline
\end{tabular}

By analyzing Table 5, the conclusion can be drawn that in the period from 2010 to 2014, a total of 78 suspended sentences with protective supervision were pronounced (Belgrade Centre for Human Rights, 2015: 16), which is approximately 600 times less as compared to the total number of suspended sentences for the same period (70738).

\section{CONCLUDING REMARKS}

Our criminal legislation recognizes two types of conditional sentence: suspended sentence and suspended sentence with protective supervision. Despite the fact that both types of suspended sentence are envisaged as a substitute for short-term penalties of deprivation of liberty, the so-called classical suspended sentence is most frequently pronounced criminal sanction in domestic practice, regardless of different economic, political and other societal conditions and stability of the country, as confirmed by the results of the conducted research. On the other hand, a suspended sentence with protective supervision, as a modality of the basic form, was rarely applied in practice. The reasons for such a small number of pronounced suspended sentences with protective supervision are multiple and include the deficit of material and technical as well as human resources in the observed period. In the last decade, a number of activities have been undertaken, with the aim of applying this measure more often. Significant progress in this regard is the adoption of the new Act on the Execution of Non-Custodial Sanctions, which regulates in detail the competence of the Trust Service. By improving the conditions for the implementation of this measure, including strengthening the existing capacities of the Trust Service, it is realistic to expect that the number of pronounced suspended sentences with protective supervision will show in the coming period a trend of growth, which is very important given that this criminal sanction proved to be very efficient in comparative legislation.

\section{REFERENCES}

Bejatović, Stanko(1986). Uslovna osuda (Suspended Sentence), NIO Poslovna politika, Beograd Belgrade Centre for Human Rights, (2015). Reducing the Overcrowding of Correctional Institutions in Serbia: The Effects of the Strategy for Reducing Overcrowding of Accommodation Facilities in Institutions for the Execution of Criminal Sanctions in the Republic of Serbia in the period 2010-2015

Krivični zakonik Bosne i Herzegovine (Criminal Code of Bosnia and Herzegovina), Službeni glasnik BiH", 3/03, 32/03, 37/03 54/04, 61/04, 30/05, 53/06, 55/06, 32/07, 8/10, 47/14, 22/15, 40/15.

Kazneni zakon Republike Hrvatske,(Criminal Code of Republic of Croatia), Narodne novine, Republike Hrvatske, 125/11, 144/12, 56/15, 61/15 
Krivični zakonik Republike Srbije (Criminal Code of Republic of Serbia) Službeni glasnik Republike Srbije, br. 85/2005, 88/2005, 107/2005, 72/2009, 111/2009, 121/2012, 104/2013, 108/2014 i 94/2016

Đokić, I., (2007), Uslovna osuda (Suspended Sentence), InIgnjatović, Đ. (ed), The state of crime in Serbia and legal means of reacting,Belgrade, Faculty of Law, University of Belgrade, 2007, pp. 187-197

Đorđević, M., (2011), Uslovna osuda sa zaštitnim nadzorom u krivičnom pravu Republike Srbije (Suspended sentence with protective supervision in the Criminal Law of the Republic of Serbia), pre-doctoral paper, Faculty of Law, University of Belgrade, Belgrade

Zakon o izvršenju vanzavodskih sankcija i mera (Act on the Execution of Non-Custodial Sanctions and Measures), Službeni glasnik Republike Srbije, 55/2014

Malešević, S., Počuča, S., (2016), Alternativne sankcije u krivičnom zakonodavstvu Srbije (Alternative sanctions in criminal legislation of Serbia), Kultura polisa, Vol. 13, No. 30, 2016, pp. 389-400

Pradel, Ž., (2009), Komparativno krivično pravo: sankcije (Comparative Criminal Law: Sanctions), Pravni fakultet Univerziteta u Beogradu, Beograd

Pravilnik o izvršenju uslovne kazne sa zaštitnim nadzorom (Rules on the Execution of Suspended Sentence with Protective Supervision), Službeni glasnik Republike Srbije, 20/2008

Sevdiren, Ö., (2011), Alternatives to Imprisonment in England and Wales, Germany and Turkey: A Comparative Study, Springer, New York

Simić, I., (1998), Zbirka sudskih odluka iz krivičnopravne materije(Collection of court decisions from criminal law), Službeni glasnik, Beograd

Simić, I., (2000), Zbirka sudskih odluka iz krivičnopravne materije(Collection of court decisions from criminal law), Službeni glasnik, Beograd

Soković, S., (2009). Između zatvora i uslovne osude-intermedijarne sankcije (Between prison and suspended sentence-intermediate sanctions), Revija za kriminologiju i krivično pravo, Vol. 47, No.3, 2009, pp. 183-196.

Stojanović, Z., (2016), Krivično pravo - opšti deo (Criminal Law - general part), Pravni fakultet Univerziteta u Beogradu, Pravna Knjiga, Beograd

Stojanović, Z., (2012), Komentar Krivičnog zakonika (Commentary on the Criminal Code), Službeni glasnik, Beograd

Trešnjev, A., (2008), Zbirka sudskih odluka iz krivičnopravne materije (Collection of court decisions from criminal law), Službeni glasnik, Beograd

Veković, V., (2012), Mere upozorenja: krivičnopravni, kriminalnopolitički, procesni i izvršni aspekt (Cautionary measures: Criminal, criminal-political, procedural and executive aspects), In: Krvavac, M. (ed), Zbornik radova Pravnog fakulteta u Prištini, Univerzitet u Prištini, 2012, pp. 43-55

Weatherburn, D., Bartels, L., (2008), The recidivism of offenders given suspended sentences in New South Wales, Australia, British Journal of Criminology, Vol. 48, No. 5, 2008, pp. 667-683.

\section{USLOVNA OSUDA U KRIVIČNOM ZAKONODAVSTVU REPUBLIKE SRBIJE}

Uslovna osuda, kao mera upozorenja, predstavlja jednu od najčešće primenjivanih krivičnih sankcija i kao takva postoji u skoro svim savremenim zakonodavstvima. Od svog nastanka do današnjih dana uvek aktuelna, izaziva neprekidnu pažnju i interesovanje stručne javnosti. U tekstu koji sledi, nakon kratkog pregleda istorijskog razvoja uslovne osude, biće analizirana uslovna osuda u krivičnom pravu Republike Srbije, odnosno pojam i karakteristike uslovne osude, uslovi za izricanje uslovne osude, opozivanje uslovne osude i uslovna osuda sa zaštitnim nadzorom. U drugom delu biće prikazana primena uslovne osude u Srbiji, gde će se, na osnovu statističkih podataka, izvršiti komparativni pregled učestalosti izricanja uslovne osude u tri vremenska perioda sa međusobno različitim političkoekonomskim i drugim obeležjima (period sedamdesetih, devedesetih godina i period nakon demokratskih promena).

Ključne reči: mere upozorenja, uslovna osuda, uslovna osuda sa zaštitnim nadzorom, vreme proveravanja. 